\title{
NEUTRONICS ANALYSIS ON MINI TEST FUEL IN THE RSG-GAS CORE
}

\author{
Tukiran S, Tagor MS \\ BFTR-PTKRN-BATAN, Kawasan Puspiptek Serpong 15310 \\ Email: tukiran@batan.go.id \\ Diterima editor: 18 Desember 2015 \\ Direvisi editor: 12 Januari 2016 \\ Disetujui untuk publikasi: 15 Februari 2016
}

\begin{abstract}
NEUTRONICS ANALYSIS ON MINI TEST FUEL IN THE RSG-GAS CORE. Research on UMo fuel for research reactor has been developed. The fuel of research reactor is uranium molybdenum low enrichment with high density. For supporting the development of fuel fabrication, an neutronic analysis of mini fuel plates in the RSG-GAS core was performed. The aim of analysis is to determine the numbers of fuel cycles in the core to know the maximum fuel burn-up. The mini fuel plates of U7Mo-Al and U6Zr-Al with densities of $7.0 \mathrm{gU} / \mathrm{cc}$ and $5.2 \mathrm{gU} / \mathrm{cc}$, respectively, will be irradiated in the RSG-GAS core. The size of both fuels, namely $630 \times 70.75 \times 1.30 \mathrm{~mm}$ were inserted to the 3 plates of dummy fuel. Before the fuel will be irradiated in the core, a calculation for safety analysis from neutronics and thermal-hydraulics aspects were required. However, in this paper, it will be discussed safety analysis of the U7Mo-Al and U6Zr-Al mini fuels from neutronic point of view. The calculation was done using WIMSD-5B and Batan-3DIFF codes. The result showed that both of the mini fuels could be irradiated in the RSG-GAS core with burn up less than $70 \%$ within 12 cycles of operation without over limiting the safety margin. If it is compared, the power density of U7Mo-Al mini fuel is bigger than U6Zr-Al fuel.
\end{abstract}

Key words: mini fuel, neutronics analysis, reactor core, safety analysis

\section{ABSTRAK}

ANALISIS NEUTRONIK ELEMEN BAKAR UJI MINI DI TERAS RSG-GAS. Penelitian tentang bahan bakar UMo untuk reaktor riset terus berkembang saat ini. Bahan bakar reaktor riset yang digunakan adalah uranium pengkayaan rendah namun densitas tinggi. Untuk mendukung pengembangan bahan bakar dilakukan uji elemen bakar mini di teras reaktor RSG-GAS dengan tujuan menentukan jumlah siklus di dalam teras sehingga tercapai fraksi bakar maksimum. Bahan bakar yang diuji adalah U7Mo-Al dengan densitas 7,0 gU/cc dan U6Zr-Al densitas 5,2 gU/cc. Ukuran kedua bahan bakar uji tersebut adalah sama 630x70,75x1,30 mm dimasukkan masing masing kedalam 3 pelat dummy bahan bakar. Sebelum diiradiasi ke dalam teras reaktor maka perlu dilakukan perhitungan keselamatan baik secara neutronik maupun termohidrolik. Dalam makalah ini akan dibahas analisis keselamatan uji bahan bakar mini U7Mo-Al dan U6Zr-Al ditinjau dari segi neutronik. Perhitungan dilakukan dengan menggunakan program komputer WIMSD-5B dan Batan-3DIFF. Hasil analisis menunjukkan bahwa kedua bahan bakar uji dapat diiradiasi dengan derajat bakar $<70 \%$ selama 12 siklus operasi tanpa melampaui batas keselamatan neutronik. Kerapatan panas bahan bakar uji U7Mo-Al lebih besar dari bahan bakar U6Zr-Al.

Kata kunci: Bahan bakar mini, analisis neutronik, teras reaktor, analisis keselamatan 


\section{INTRODUCTION}

Research and development of nuclear fuel for research reactor has been being done continually by researchers in the world based on uranium utilization and it has changed the orientation from high enrichment uranium (HEU) to low enrichment uranium (LEU) which was first launched by the USA in 1978 [1]. The new fuel research is covered from several aspect of view and all research goals are to get a new fuel for a research reactor which capable to increace a higher density. The uranium fuels enriched to more than $90 \%$ of ${ }^{235} \mathrm{U}$. It has been used for many peaceful applications requiring high fissile material densities. These efforts include the development of high-density fuels to replace the low volume-density based HEU fuels. This led to the development and qualification of an $\mathrm{U}_{3} \mathrm{Si}_{2}$ - $\mathrm{Al}$ based dispersion fuel with a uranium density of $4.8 \mathrm{gU} / \mathrm{cc}$ in the 1990s [2]. The typical fuel design for many European research reactors is an assembly of thin fuel plates consisting of a central layer of a fuel compound dispersed in a pure Al matrix. This layer is sandwiched between cladding sheets made from an $\mathrm{Al}$ alloy. Fuel plates are manufactured using hot and cold rolling processes.

By the end of the 1990s, most reactors capable of core conversion to Low-Enriched Uranium (LEU) using $\mathrm{U}_{3} \mathrm{Si}_{2}-\mathrm{Al}$ were converted [2]. Attention was then turned to the remaining high-power reactors that were unable to use $\mathrm{U}_{3} \mathrm{Si}_{2}-\mathrm{Al}$ without severe performance losses. Additional fuel development was required to allow conversion of these reactors. A fuel loading of $6.5-8.5 \mathrm{gU} / \mathrm{cc}$ is required for most of these reactors, although some are believed to require even higher densities only available in alternative fuel designs, such as the monolithic UMo fuel, which is mostly developed in the USA. The USA, the main driving force behind the conversion requirements and an important supplier of HEU, led the efforts with a number of coping studies to identify appropriate fuel candidates [3]. This involved the irradiation of a number of high-density uranium compounds from which the UMo alloys with a Mo content of 7-10 w\% were chosen as the best candidates [4]. The selection was based on good irradiation behavior, sufficiently high intrinsic density $(\sim 16 \mathrm{gU} / \mathrm{cc})$ and availability of historic irradiation data from research reactors. Certainly due to the relatively important cross-section of Mo for neutron capture, a fuel density of $\sim 8 \mathrm{gU} / \mathrm{cc}$ is required. This review aims to provide a synthesis of the knowledge generated and the lessons learned in roughly of UMo dispersion fuel through a series of irradiation experiments.

A lot of irradiations were also performed outside of Europe, particularly in the USA, Russia, Canada, Korea and Argentina. In addition, a large number of out-of-pile investigations were done throughout the world, providing support to the understanding of the phenomena governing the UMo behavior in pile. The first indications of failure of the UMo-Al dispersion fuel system were observed in high power irradiations. Excessive local swelling of the UMo-Al dispersion plates, described as 'pillowing', was observed in the high power zones of the plates. It turned out this was the consequence of excessive interaction between the UMo kernels and their surrounding matrix, leading to the formation of an amorphous interaction phase [5]. Nevertheless, the observed microstructural evolutions were interpreted to indicate that under high power conditions they would likely not survive either. Nevertheless, these experiments provided vital information on the behavior of UMo particles under progressing burnup accumulation and allow a general description of the phenomena occurring in this and related fuel systems. From the point of view of reactor exploitation and fuel qualification, one of the most important aspects of fuel plate behavior is its swelling. The cooling gaps between fuel plates in a research reactor plate fuel assembly are very narrow typically $2-3 \mathrm{~mm}$ and fuel plate swelling causes them to reduce further [6].

In order to assure adequate cooling throughout the lifetime of the assembly, the fuel plates should not swell excessively. Normal solid state fuel swelling under the influence of the incorporation of fission product, particularly the high yield Xe atoms, is inevitable. The amount of swelling that can be tolerated depends on the design, but should preferably not exceed 150-200 $\mu \mathrm{m}$ [7]. In addition to remaining limited, the swelling should also be controlled and be a gradual function of burn-up as uncontrolled accelerations in the swelling rate are not acceptable. Such uncontrolled swelling is often referred to as 'breakaway swelling', generated by large gas filled bubbles/cavities forming rapidly in the meat, leading to 'pillowing' of the fuel plate, i.e. the development of blisters on both sides of the fuel plate generally interpreted as being caused by the accumulation of fission gases, which exert important pressures and cause the cladding to bulge. Breakaway swelling is typically associated with 
changes in the fuel microstructure, leading to sudden increased mobility for fission gas. For the UMo$\mathrm{Al}$ dispersion fuel system with atomized $\mathrm{U}-7 \mathrm{w} \% \mathrm{Mo}$ dispersed at a loading of $\sim 8 \mathrm{gU} / \mathrm{cc}$, the observations are that plate pillowing occurs at relatively low burn-up (30-40\%), where the plate thickness increases with fission density accumulation [7]. The different power levels, plates were found to pillow at local burn-up of 35-40\%[7]. Also in the case of the IRIS- 3 plates with very low Si content $(0.3 \%)$ in the matrix, the burn-up at which pillowing was observed were very similar[8]. In IRIS-1, at low power and the initial porosity accommodating much of the early swelling, no pillowing was observed up to higher burn-up (67.5\%, UMo). Similarly, the low Si plates of the IRIS-TUM irradiation were also irradiated at moderate power up to higher burn-up (up to $56 \%{ }^{235} \mathrm{U}$ LEU equivalent burn-up) showing increased swelling rates, but without direct evidence of pillowing [8]. Although it is qualitative, there appears to be a better mechanical resistance to pillowing for the ground UMo based fuel, possibly because the anchoring of the irregularly shaped fuel particles to the matrix is better than for the spherical atomized kernels. Nevertheless, based on the microstructural evolution observed it is believed that eventually the ground fuel will also not be able to resist the internal stresses and yield, certainly at the higher power at which this fuel needs to operate. This claim was never tested in an irradiation experiment, partly because an industrially viable ground powder supply route was not as readily available to the community as for the atomized powder. As far as the evolution of the fuel microstructure with burn-up is concerned. The UMo material itself (ground or atomized) shows a very predictable and stable evolution under irradiation as a sizeable fission product inventory is built up inside it. The burn-up in research reactor fuels far exceed those known in power reactor fuels and as such the fission product (FP) concentrations and damage accumulations in the fuel particles are more important as well. Of particular importance is the behavior of noble fission gases, which tend to show important mobility and precipitate into bubbles even by a thermal mechanisms. In UMo, the fission gases were shown to initially precipitate in nano-bubbles $(2-3 \mathrm{~nm}$ diameter), which were found to be ordered in a super-lattice (6-7 nm spacing). TEM observations performed on samples of the FUTURE plates have demonstrated this behavior and were confirmed by other observations, also in ground fuel[9]. As the fission gas concentration increases, the gas eventually precipitates out into larger (micron-size) bubbles, first on the cell boundaries of the atomized kernel microstructure or the dislocations and grain boundaries in ground fuel, and later on throughout the bulk of the UMo. As the cell boundaries have a slightly lower Mo concentration.

According to BATAN program, the ability of BATAN's staffs on advanced nuclear fuel development always increases time by time, so $R \& D$ of fuel element production need to do an intensive program to get nuclear fuel fabrication according to international standard. BATAN has facility of research reactor fuel production installation (IPEBRR) where the R\&D of new fuel potential to do in the future.

Plate type fuel element has been fabricated at PT Batan Teknologi, now INUKI, the facility which has already supplied the fuel for RSG-GAS consist of $\mathrm{U}_{3} \mathrm{O}_{8}-\mathrm{Al}$ and $\mathrm{U}_{3} \mathrm{Si}_{2}$-Al fuels, low enrichment uranium with density of $2,96 \mathrm{gU} / \mathrm{cc}$. The performance of fuels are good until now and utilization of fuel in the core satisfied with burn up of $\pm 56 \%$. Then, from this result the fuel research has orientasion to the new fuel such as U7Mo-Al with high density. Using U-Mo alloys as a fuel, it has possibility to increase the density until $16.4 \mathrm{gU} / \mathrm{cc}$. The density is higher than uranium oxide or uranium silicide and the alloy is easy to fabricate. .

The U7Mo-Al and U6Zr-Al mini test fuel plates are already fabricated successfully in BATAN's facility with density of $7.0 \mathrm{gU} / \mathrm{cc}$ and $5.2 \mathrm{gU} / \mathrm{cc}$, respectively. Before the fuel will be irradiated in the RSG-GAS core, it is needed to analisys the neutronic aspect of view as a requirement from safety committee. The aim of research is to know the characteristic of fuel with high density under irradiation at the level $15 \mathrm{MW}$ of power. The several mini test fuel plates were also already irradiated in the RSG-GAS core successfully with maximum burn up $56 \%$.but different fuel material and density $\left(\mathrm{U}_{3} \mathrm{Si}_{2}-\mathrm{Al}, 4.8 \mathrm{gU} / \mathrm{cc}\right.$ and $\left.5.2 \mathrm{gU} / \mathrm{cc}\right)$ Based on this experience, it will be irradiated the mini test fuel plate element at G-7 irradiation position at RSG-GAS core. The aim of mini test fuel irradiation is to know the fuel characterics under irradiated until $70 \%$ of burn up. It can be determined by calculation the numbers of fuel cycles in the core to get the maximum fuel burn-up. The mini fuels that will be iradiated in the RSG-GAS core are U7Mo-Al and U6Zr-Al with densities of $7.0 \mathrm{gU} / \mathrm{cc}$ and $5.2 \mathrm{gU} / \mathrm{cc}$, respectively. The size of both fuels, namely $630 \times 70.75 \times 1.30 \mathrm{~mm}$ were inserted to the 3 
plates of dummy fuel. Before the fuel will be irradiated in the core, a calculation for safety analyses from neutronics and thermal-hydraulics aspects were required. In this research, it will be discussed the neutronic safety analisys of mini test fuel plates of U7Mo-Al and U6Zr-Al with density of $7.0 \mathrm{gU} / \mathrm{cc}$ and $5.2 \mathrm{gU} / \mathrm{cc}$, respectively. The analysis was done by using WIMSD-5B and Batan-3DIFF computer codes to calculate neutronic parameter of the RSG-GAS core. Determining the effect of neutronic parameter when the mini test fuel plates inserted into the core. Figure 1 show the flowchard for core calculation in Batan-3DIFF code.

According to Korean researcher experience, the UMo fuel plates can be irradiated until $80 \%$ of U-235 burn up with $6 \mathrm{wt} \%$ and $10 \mathrm{wt} \%$ of Mo. The fuel tests measured is $100 \mathrm{~mm} \times 25 \mathrm{~mm} \times 1.40$ $\mathrm{mm}$ and 6 and $8 \mathrm{gU} / \mathrm{cc}$ in the fuels meat [10].

\section{THEORY}

\section{Power Factor Distribution}

Power factor can be defined as a power density which is resulted from a fuel divided by average power density which is resulted from all fuel in the core. Power factor $P_{i}$ can be determined by,

$$
P_{i}=\frac{q_{i}^{\cdots ”}}{q_{\mathrm{ave}}^{\text {"’ }}}
$$

Where $q_{i}{ }^{\prime \prime}$ is power density which is resulted from fuel $i$-th in watt/cc, meanwhile $q_{\text {ave }}^{\text {"” }}$ is average power density in the core in Watt/cc. average power density can be formulated with,

$$
q_{\text {ave }}^{\cdots}=\frac{1}{N} \sum_{i=1}^{n} q_{i}^{\cdots}
$$

where, $N=$ number of fuel in the core, $\mathrm{n}=\mathrm{n}^{\text {th }}$ fuel, meanwhile power peaking factor, (ppf) is the highest power factor which is resulted from a fuel in the core and can be defined as maximum power density $q_{\max }^{\prime \prime}$ divided by average power density $q_{\text {ave }}^{\cdots}$. Power peaking factor, ppf can be determined with ,

$$
p p f=\frac{q_{\text {max }}^{\cdots}}{q_{\text {ave }}^{\text {”. }}}
$$

\section{Design of Mini Test Fuels}

Research on U7Mo-Al and U6Zr-Al fuels with desitity of $7.0 \mathrm{~g} / \mathrm{cc}$ and $5.2 \mathrm{gU} / \mathrm{cc}$, respectively, start from U7Mo and U6Zr ingots were made by melting uranium and Mo metals with enrichment of $19,75 \%$. Uranium and Mo are high pure metals with composition of $93 \mathrm{wt} \% \mathrm{U}$ and $7 \mathrm{wt} \%$ of Mo for U7MO fuel. Meanwhile, for U6Zr fuel, the composition of $U$ and $\mathrm{Zr}$ are $94 \mathrm{wt} \%$ and $6 \mathrm{wt} \%$, respectively. The U7Mo and U6Zr ingots were made from melting became a powder by hidridingdehidriding-miling process. Then, the powder that is meet the criteria as a dispertion fuel were mixed with $\mathrm{Al}$ powder as a matrix. Weight comparison between $\mathrm{U} 7 \mathrm{Mo}, \mathrm{U} 6 \mathrm{Zr}$ and $\mathrm{Al}$ matrix in mini test fuels are determined from experiment data of U7Mo, U6Zr and Al powder. Every mini test fuel element is covered by cladding made from $\mathrm{AlMg}_{2}$ material. Then, they are formed to become U7Mo$\mathrm{Al}$ and U6Zr-Al fuels by hot and cold rolling. After the mini fuels had been done several test, and then it was fabricated to mini fuel plate which it is ready to test in the RSG-GAS reactor. The dimensions of the mini fuel test are $630 \mathrm{~mm}$ in lenght, $70.75 \mathrm{~mm}$ in width, and $1.30 \mathrm{~mm}$ in thickness, which consist of fuel meat dimension of $150 \times 15 \times 0.6 \mathrm{~mm}$. Figure 1 is flowchart of core calculation for determining a neutronic safety. Figure 2 is working core of RSG-GAS reactor where the U7Mo-Al and U6Zr-Al mini test fuels is inserted into G7 position. The dummy fuel assembly that is used for U7Mo-Al mini test fuel with density of $7.0 \mathrm{gU} / \mathrm{cc}$ and U6Zr-Al with density of $5.2 \mathrm{gU} / \mathrm{cc}$ consist of 21 fuel plates as showed in Figure 3. In this assembly the 3 mini plates of U7Mo-Al fuel are inserted into plate number 2, 4 and 6. Meanwhile 3 mini plates of U6Zr-Al fuel are inserted into number 16, 18 and 20 like showed in figure 4 . The others 15 plates in the assembly are fabricated as dummy fuel, no uranium fuel. 


\section{METHODOLOGY}

The aim of neutronic safety aspect analyses for mini test fuel plate with high density is to determine the axial posistion of target in the assembly that can be changed the core reactivity and heat generation in smallest one. In this study, it is also determined the burn up in every ending cycle of operation. From this calculation it can be determined a maximum irradiation time in the core.

Safety analisys from neutronic aspect of view is done by several calculations with WIMSD-5B and Batan-3DIFF[11] computer codes as showed in Table 1. The WIMSD-5B code is used to generate cell calculation to get cross section constant like noutron diffusion, sigma absorbtion, sigma fission for mini test fuel plates (MTFP) of U7Mo-Al and U6Zr-Al fuels, with density of $7.0 \mathrm{gU} / \mathrm{cc}$ and $5.2 \mathrm{gU} / \mathrm{cc}$, respectively. The cross section constant of U7Mo-Al and U6Zr-Al fuels as a burn up function with 17 steps[12]. The multi slabs mothed that is used in this calculation for WIMSD-5B code input. The cross section is formed with geometry of the core as an input to core calculation by BATAN-3DIFF code to determine the core reactivity change, radial and axial power peaking factor distribution, heat generation in the target and also flux neutron. The BATAN-3DIFF code is also used to calculate the radial and axial power peaking factor as a function of control rods position. Flowchart of core calculation for BATAN-3DIFF code is shown in Figure 1.

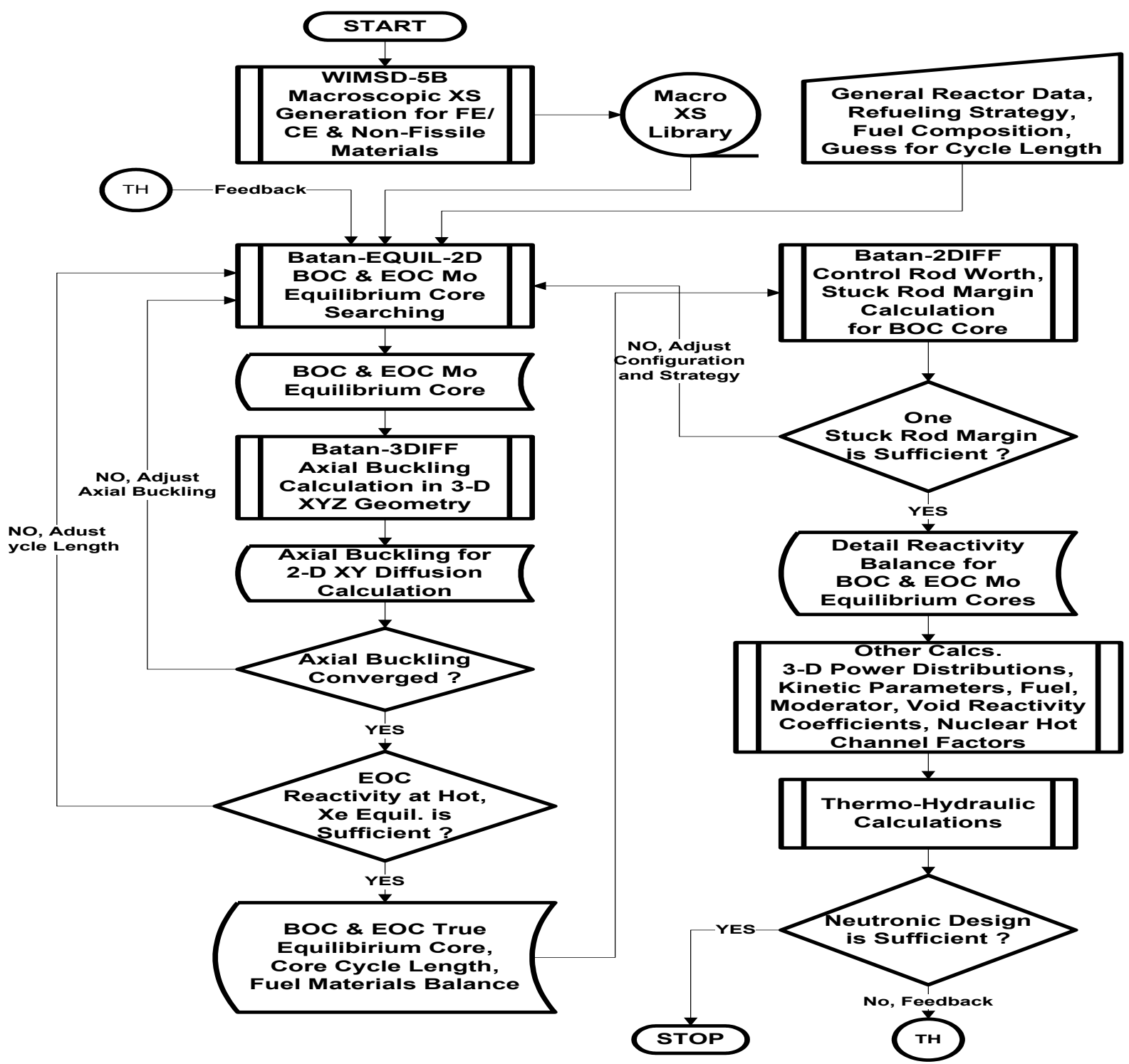

Figure 1. Flowchart of core calculation for Batan-3DIFF code [13] 
Tablel 1. Code that is used for core calculation of RGS-GAS reactor

\begin{tabular}{cllc}
\hline No. & \multicolumn{1}{c}{ Calculation } & \multicolumn{1}{c}{ Method } & Code \\
\hline 1. & $\begin{array}{l}\text { Macroscopics cross section for } \\
\text { U7Mo-Al and U6Zr-Al target as } \\
\text { a burn up function }\end{array}$ & $\begin{array}{l}\text { Neutron transport }\left(\mathrm{S}_{N}\right) \text { theory with } \\
\text { multi neutron energy group }\end{array}$ & WIMSD-5B \\
$\begin{array}{l}\text { Core reactivity calculation after } \\
\text { and before target inserted into the } \\
\text { core }\end{array}$ & $\begin{array}{l}\text { Neutron Diffusion with 3- } \\
\text { dimension }\end{array}$ & Batan-3DIFF \\
\hline
\end{tabular}

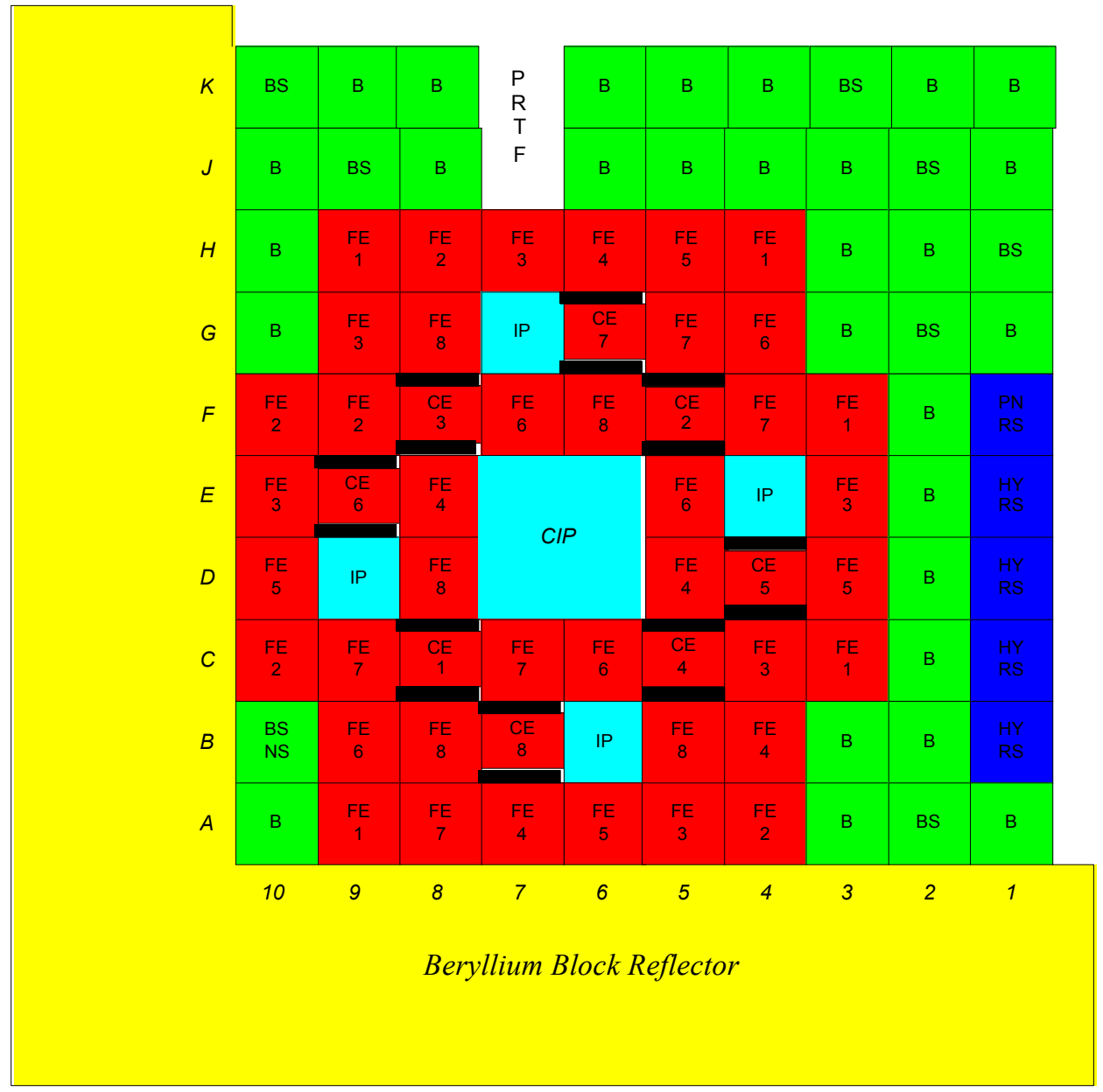

noted $\quad: \mathrm{EB}=$ Fuel elements, $\mathrm{EK}=$ Conrol rods, $\mathrm{BE}=\mathrm{Be}$ reflector element

, BS $=$ Be Reflector element with , IP = Irradiation position,

$\mathrm{CIP}=$ Central Irradian Position, PNRS $=$ Pneumatic Rabbit System,

HYRS = Hydraulic Rabbit System (Burn up class at second row )

Figure 2. RSG-GAS TWC configuration core

Before the calculation was done, it is needed to determine the grid position for mini test fuel plate irradiation in the RSG-GAS core. Based on neutronic calculation, the irradiation position that can be used to get smallest effect to the core reactivity change is in the G-7 grid position and it can be seen in Figure 2. Therefore, the G-7 irradiation position was determined as the best position to irradiate mini test fuel plates in the RSG-GAS core. But the criteria to analyze the neutronic calculation for mini plates are:

- Maximum core reactivity change for inserting the mini test fuel plate into the RSG-GAS core is $0,5 \% \Delta k / k$. 
- As mini test fuel plate inserted into the core, one stuck rod criteria must be fulfiled with safety margin $\geq 0,5 \% \Delta k / k$.

- The maximum value of axial peaking power factor is not more than 1.4.

Calculation steps:

1. Determination axial position of the mini test fuel plate (target). The active height of the target is $15 \mathrm{~cm}$, so the axial position target must be determined with minimum effect to the core. The axial position to put the mini plate in the fuel assembly start from $7.5 \mathrm{~cm}, 17.5 \mathrm{~cm}, 27.5 \mathrm{~cm}, 30 \mathrm{~cm}$, $37.5 \mathrm{~cm}$ and $47.5 \mathrm{~cm}$ from top

2. Determination of axial heat density change when mini test fuel plate is inserted into the core as a function of control rods position.

3. Determination of burn up at every ending cycle operation to get the time irradiation and number of cycles. The maximum burn up is not more than $70 \%$.

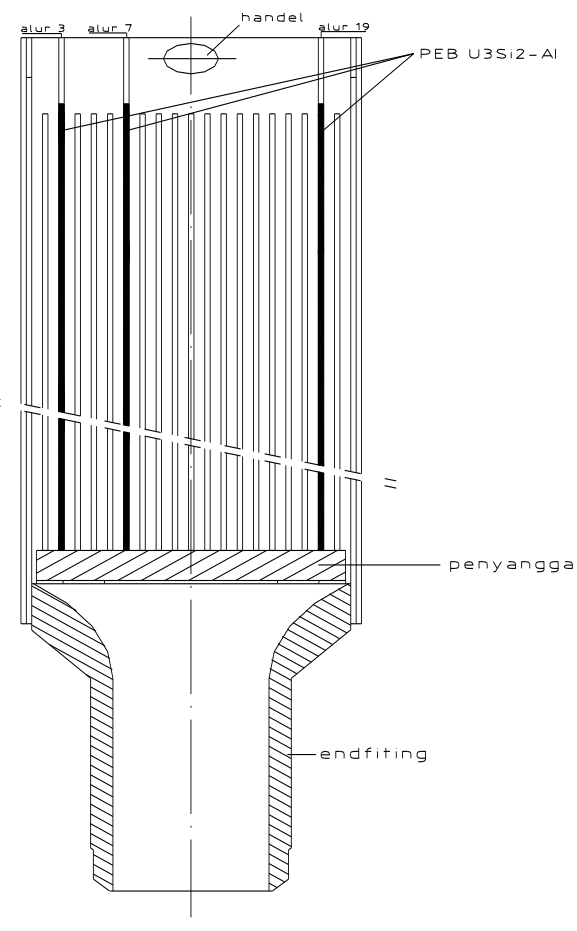

Figure 3. Fuel element of RSG-GAS

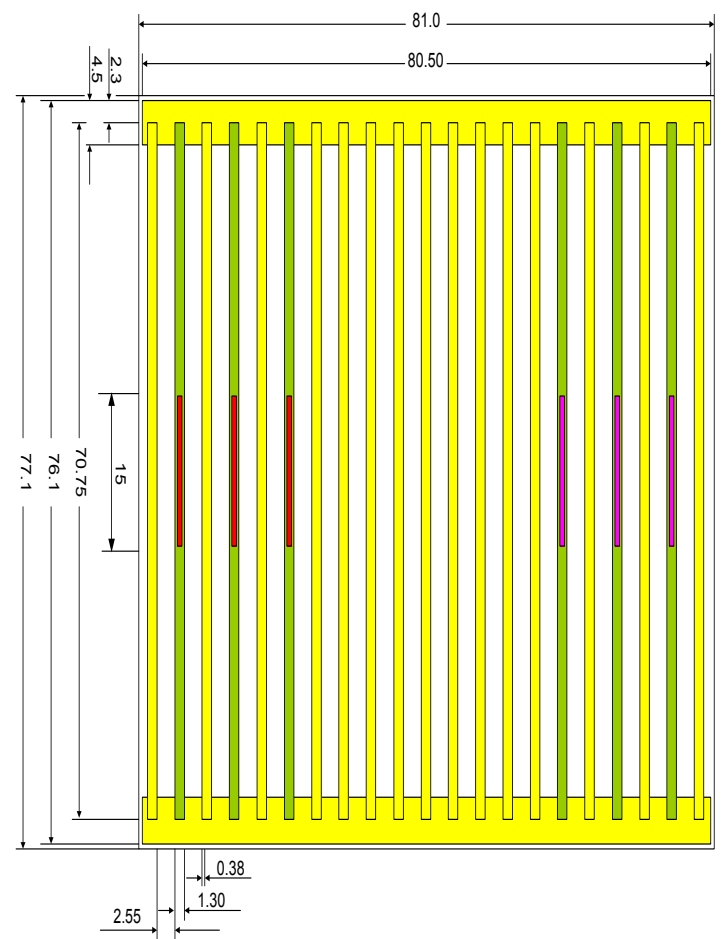

Figure 4. UMo and UZr mini test plates

\section{RESULT AND DISCUSSION}

\section{Determination of axial posisition mini test fuel target in the core}

Table 2 and Figure 5 show the core reactivity change $(\Delta \rho, \% \Delta k / k)$ and the heat generation in the mini test fuel target $(\mathrm{W} / \mathrm{cc})$. The value of core reactivity change will be higher at mid-position of the irradiation position of G7 RSG-GAS core around $30 \mathrm{~cm}$ from the top in the active core. Maximum reactivity change occurs at the position of the target at $27.5 \mathrm{~cm}$ and $30 \mathrm{~cm}$ which has the value of 0.27 $\% \Delta k / k$. Because at this position, when the target in the RSG-GAS core give the reactivity change effect to core of $0.27 \% \Delta k / k$ and generated the heat around $8095.59 \mathrm{~W} / \mathrm{cc}$. Then, the value of maximum heat generation is 8370.42 for U7Mo-Al and $6777.80 \mathrm{~W} / \mathrm{cc}$ for U6Zr-Al fuels, respectively. Both of them occurs at $37.5 \mathrm{~cm}$ for axial position of target. Table 2 and Figure 5 also show that minimum values for core reactivity change and heat generation occurs at $7.5 \mathrm{~cm}$ axial position. The result from this calculation show that mini test target design must put at this position at the active zone $7.5 \mathrm{~cm}$ from the top. 
Table 2. Core parameter as a function of target axial position

\begin{tabular}{ccccc}
\hline $\begin{array}{c}\text { Axial } \\
\text { position of } \\
\text { target }(\mathrm{cm})\end{array}$ & $\begin{array}{c}\text { Core } \\
\text { reactivity } \\
\text { change } \\
(\% \Delta \mathrm{k} / \mathrm{k})\end{array}$ & $\begin{array}{c}\text { Heat density in plate } \\
\text { of U7Mo-Al fuel } \\
(\mathrm{W} / \mathrm{cc})\end{array}$ & $\begin{array}{c}\text { Heat density in plate of } \\
\text { U6Zr-Al fuel (W/cc) }\end{array}$ & $\begin{array}{c}\text { radial PPFat } \\
\text { mini plate fuel. }\end{array}$ \\
\hline 7.5 & 0.20 & 6437.38 & 5214.34 & \\
17.5 & 0.24 & 8065.95 & 6531.04 & 0.01 \\
27.5 & 0.27 & 8271.72 & 6699.12 & 0.02 \\
30 & 0.27 & 8095.59 & 6557.06 & 0.02 \\
37.5 & 0.26 & 8370.42 & 6777.80 & 0.02 \\
47.5 & 0.22 & 7574.97 & 6130.01 & 0.01 \\
\hline
\end{tabular}

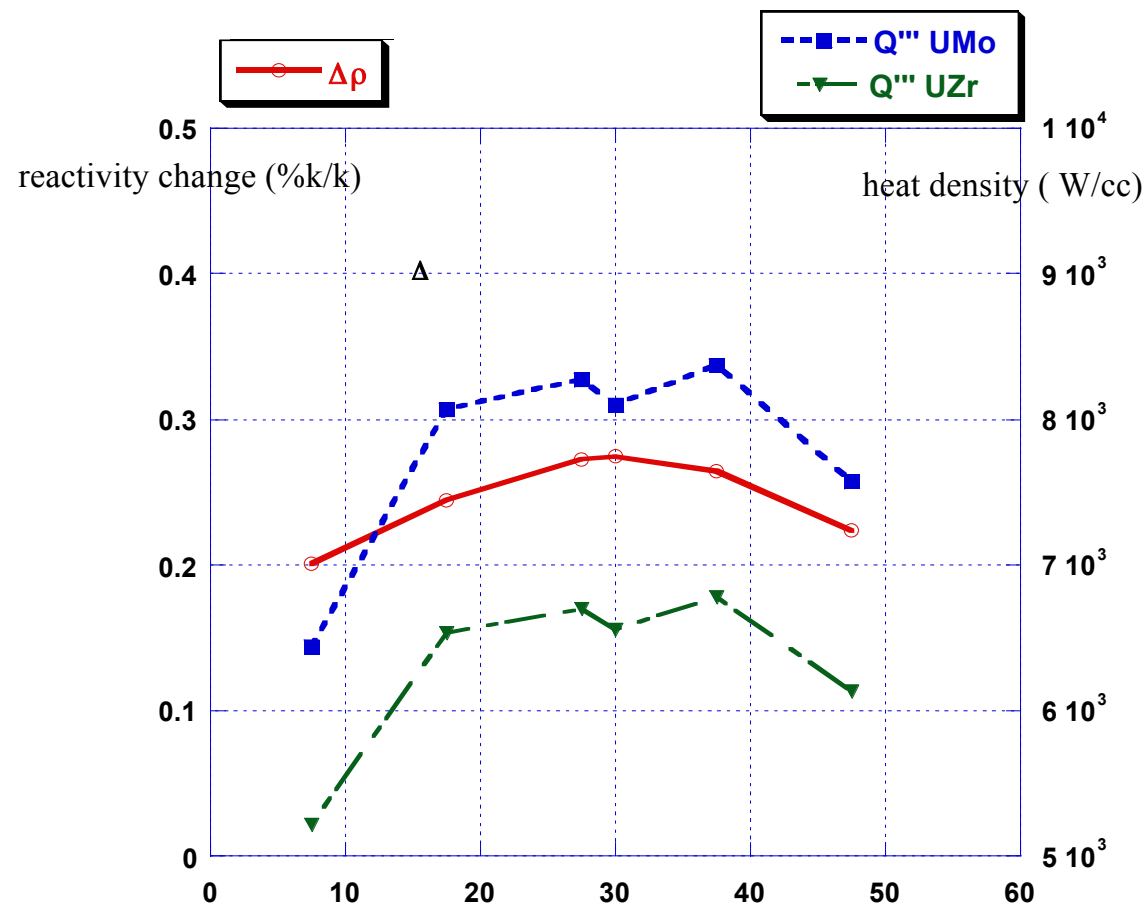

Axial target position ( $\mathrm{cm})$

Figure 5. Core reactivity change vs heat density as a function of axial position

\section{Heat density as function of control rod position}

When the mini test fuel plates are inserted into the RSG-GAS core, the control rod position will change. The change of control rods position will change the neutron flux distribution along axial position, so that the axial heat generation also change. Figure 6 and 7 showed that heat generation for $\mathrm{U} 7 \mathrm{Mo}-\mathrm{Al}$ and $\mathrm{U} 6 \mathrm{Zr}-\mathrm{Al}$ mini test fuel plate also change as a function of control rod position . 


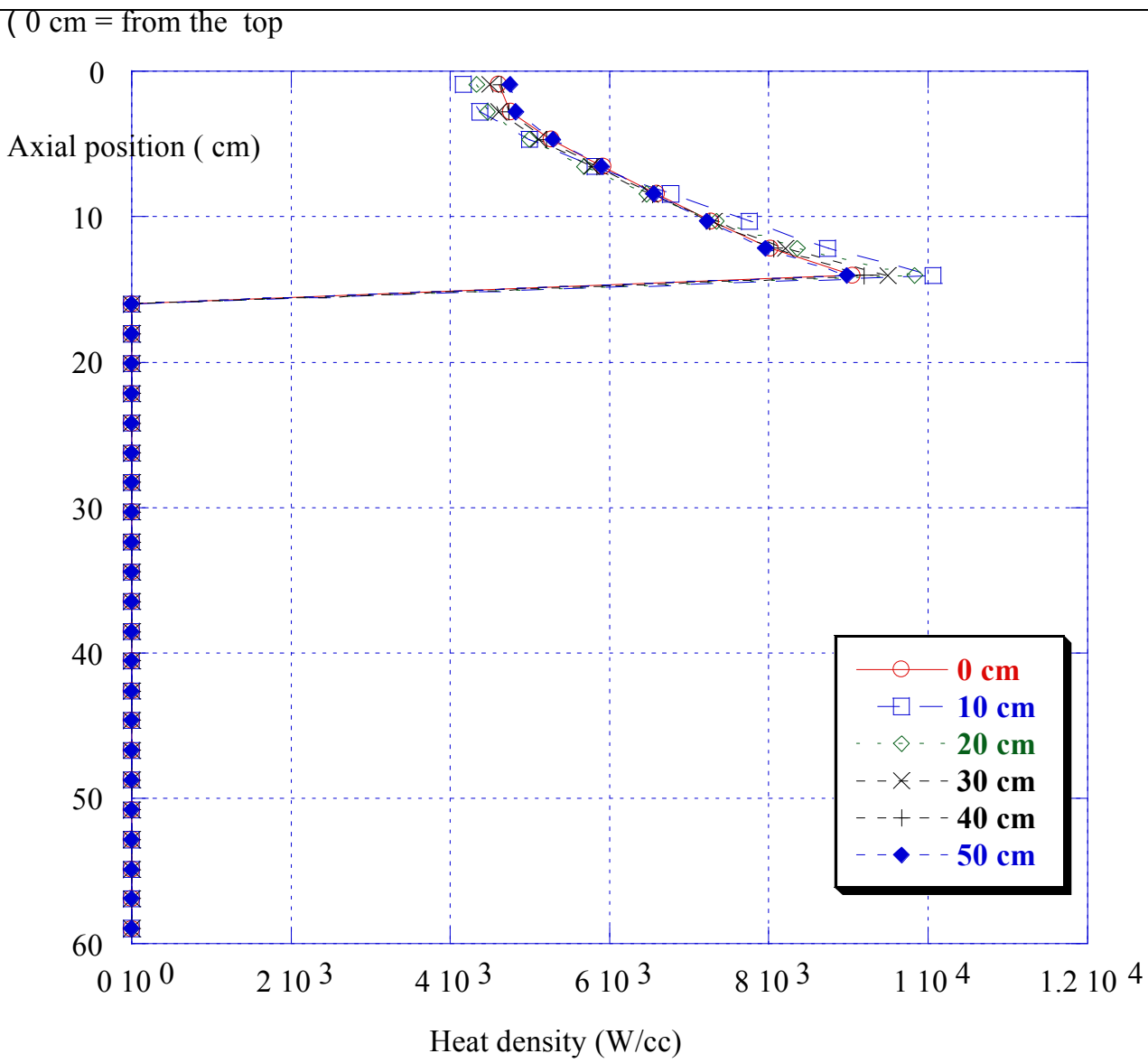

Figure 6. Axial heat density of U7Mo-Al fuel as a function of control rod position

It can be seen clearly in figure 6, for U7Mo-Al mini test fuel plates, the axial heat density changed as a function of controd rods position. The maximum value of axial heat density is $10,068.07$ $\mathrm{W} / \mathrm{cc}$ when control rod position is inserted $10 \mathrm{~cm}$. The minimum value is $8,986.59 \mathrm{~W} / / \mathrm{cc}$ achived when the position of control rod at $50 \mathrm{~cm}$. The same situation also occurs for $\mathrm{U} 6 \mathrm{Zr}-\mathrm{Al}$ mini test fuel plates in Figure 7. When the control rod is inserted $10 \mathrm{~cm}$, it achived the maximun value of heat density at $7,920.58 \mathrm{~W} / \mathrm{cc}$ and when the control rod is inserted $50 \mathrm{~cm}$, it achieved the minimum value of heat density at 7,206.21 W/cc. Based on this calculation, thermohydraulic aspect can be analized to determine the safety criteria at the worst condition. Safety aspect of this analysis will be used the data from maximum heat density distribution when the control rod is inserted $10 \mathrm{~cm}$. 


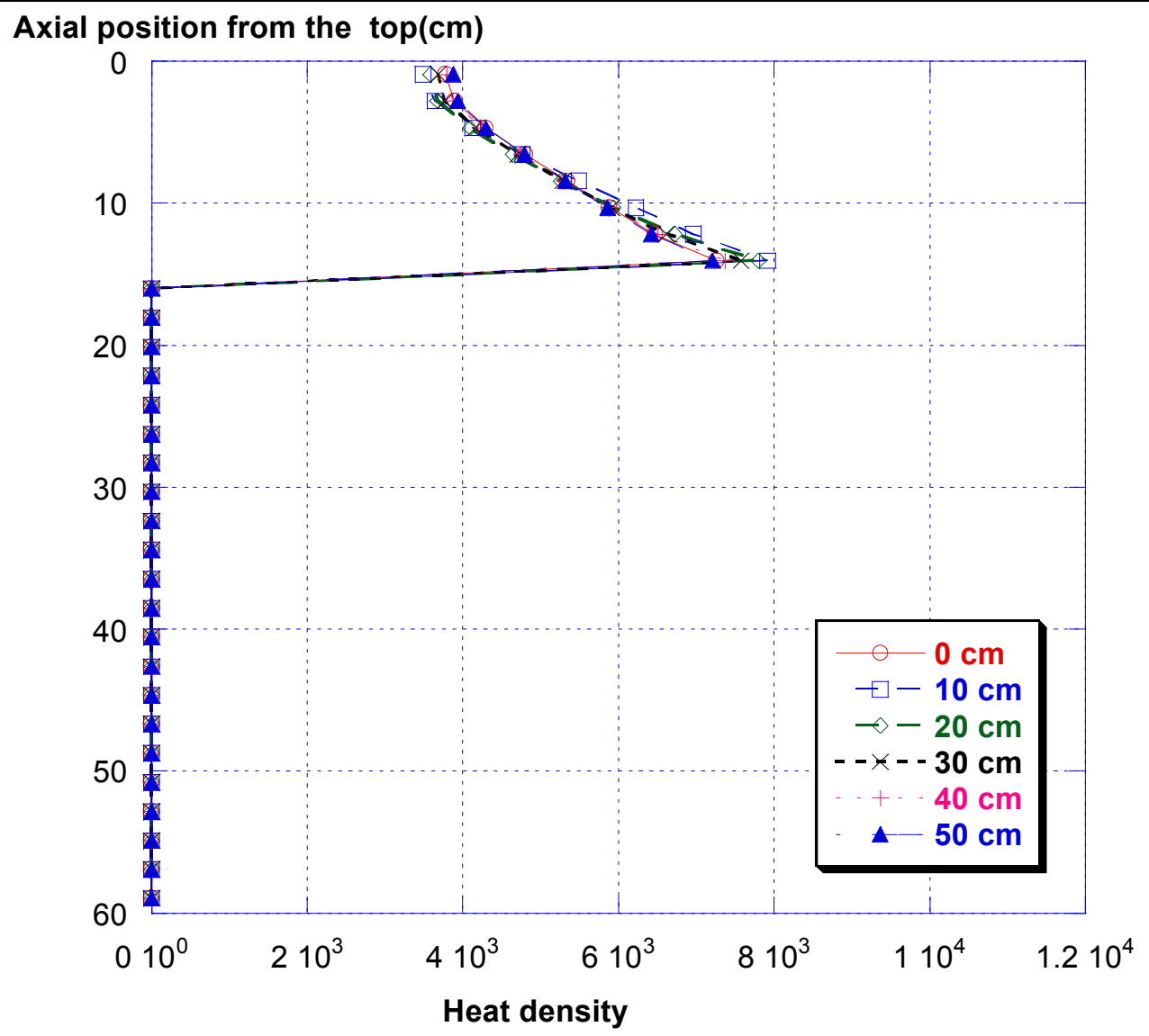

Figure7. Axial heat density of U6Zr-Al fuel as a function of control rod function

\section{Mini test fuel burn up}

Table 3 showed that burn up of mini test fuel plates at every end of cycle (EOC) when irradiated in the G-7 irradiation position of RSG-GAS core. It was achieved that burnup rate of U7Mo$\mathrm{Al}$ target higher than U6Zr-Al target, if they were compared between both of them. So that, after 11 cycles U7Mo-Al target has achieved burn up of $61.7 \%$. Meanwhile for U6Zr-Al fuel, the burn up is about $56.76 \%$. This occurs because power peaking factor of U7Mo-Al mini test fuel plates higher than U6Zr-Al mini test fuel plates. The safety margin is limited at $70 \%$, so the irradiation is stopped until 12th step cycles because it can be occured something that is unwilling situasion for the mini test fuel plates.

Table3. Target burn-up of U7Mo-Al and U6Zr-Al mini fuels at EOC

\begin{tabular}{ccc}
\hline \multirow{2}{*}{ Step cycles } & \multicolumn{2}{c}{ Average burn-up (\%) } \\
\cline { 2 - 3 } & U7Mo-Al target & U6Zr-Al target \\
2 & 7.62 & 6.84 \\
3 & 14.58 & 13.12 \\
4 & 21.17 & 19.10 \\
5 & 27.41 & 24.78 \\
6 & 33.30 & 30.17 \\
7 & 38.85 & 35.27 \\
8 & 44.06 & 40.10 \\
9 & 48.95 & 44.65 \\
10 & 53.52 & 48.94 \\
11 & 57.78 & 52.98 \\
12 & 61.75 & 56.76 \\
& 65.43 & 60.31 \\
\hline
\end{tabular}


Table 4. Result of neutronic calculation with Batan-2 DIFF code

\begin{tabular}{lcc}
\hline RSG-GAS core condition & Core reactivity $(\% \Delta \mathbf{k} / \mathbf{k})$ & Maximum PPF \\
\hline No mini fuel target & - & 1.19 \\
Mini fuel target at G7 irradiation posision & 0.27 & 1.21 \\
Neutronics safety margin & 0.50 & 1.40 \\
\hline
\end{tabular}

Table 4 shows that it is not break the safety margin from neutronic aspect of view when the mini test fuel plate was inserted at G-7 irradiation position in the core. The core reactivity change is only $0.27 \% \Delta \mathrm{k} / \mathrm{k}$, it is not more than safety criteria limitation $(0.5 \% \Delta \mathrm{k} / \mathrm{k})$. It is also occured for maximum PPF of fuel in the core, the value change from 1.19 to 1.21 and the criteria or safety margin is not more than 1.4. So the irradiation of the mini test fuel plates can be done in the core of RSGGAS reactor where core configuration of silicide fuel.

RGS-GAS reactor was already irradiated the silicide mini test fuel plate. the advantage of UMo fuel compare to silicide fuel is about the discharged burn up. For the silicide fuel the burn up is limited until $56 \%$ but for UMo fuel it can be increased until arround $70 \%(<70 \%)$. Besides the fuel burn up for UMo fuel become advantage. The advantage for UMo occurs also at fuel design make time irradiation in the core will also increase. It meant that fuel cost will save and get an advantage.

\section{CONCLUSION}

Neutronic analysis of mini test fuel plates irradiation resulted that target can be irradiated in RSG-GAS core with no break the safety margin. The mini test fuel plate was irradiated with the burn up around $70 \%$. The U7Mo-Al with density of $7.0 \mathrm{gU} / \mathrm{cc}$ can be irradiated with U6Zr-Al mini fuels at density of $5.2 \mathrm{gU} / \mathrm{c}$ as well. But the maximum burn up achieved first for U7Mo-Al because its heat density higher than U6Zr-Al fuel. The maximum heat density will be achieved when the control rods position $10 \mathrm{~cm}$ from the top. For U7Mo-Al fuel, the value of maximum heat density is around 9.986,59 W/cc. Meanwhile for U6Zr-Al is around 7.920,58 W/cc. Based on this analysis the mini test fuel plates can be irradiated in G-7 position of the RSG-GAS core because it meets the safety margin from neutronic aspect of view. The analisys will be countinued from thermalhydraulic aspect of view that used the data of maximum heat density.

\section{Acknowledgement}

Special thanks are due to Prof. Dr. Liem Peng Hong who provided one of the code i.e., Batan3DIFF, used in this study. Thanks also give to Prof. Drs. Surian Pinem MSi and Dr. Jupiter Sitorus Pane MSc for their suggestion and discussion.

\section{REFERENCES}

1. S.Van Den Berghe, P. Lemoine. Review of 15 years of high-density low enriched UMo dispersion fuel development for research reactor in Europe. Nucl. Eng. and Technology, 2014;14:125-146.

2. E. A. Villarino. "Core Performance Improvements using High Density Fuel in research Reactors.” RRFM 2013, APRIL 21-25, St Petersburg, Rusia; 2013. P.219-7.

3. Farhan Muhammad, Asad Majid. Effect of High Density Dispersion Fuel Loading on Dynamics of A Low Enriched Uranium Fueled Material Test Research Reactor. Progress in Nuclear Energy 2009;51:339-346.

4. M.K. Meyer, J. Gan, J.F. Jue, D.D. Keiser, E. Perez, A. Robinson, D.M. Wachs, N. Woolstenhulme, G.L. Hofman, Y.S. Kim. Irradiation performance of U-Mo monolithic fuel. Nuclear Engineering and Technology 2014 46;2:169-182. 
5. Hengstler R.M, et al, "Physical Properties of Monolithic U8wt.5-Mo", Journal of Nuclear Material 2010;402:74-80.

6. Teruel, F.E, Rizwan-uddin. An innovative research reactor design. Nucl. Eng. Design, 2009: 239:395-407

7. Raina, V.K., Sasidhaöran, K., Sengupta, S., Singh, T. Multipurpose research reactor. Nucl. Eng. Design 2006;236:770-783.

8. Ho Jin Ryu, Yeon Soo Kim. Influence of fuel-matrix interaction on the breakaway swelling of U-Mo dispersion fuel in Al. Nuclear Engineering and Technology 2014;46:159-168.

9. Rafael Oliveira Rondon Muniz, Adimir dos Santos, Mitsuo Yamaguchi, Pedro Carlos Russo Rossi, Douglas Borges Domingos, Luís Felipe Mura, Antonio Teixeira e Silva. Neutronic analysis of a U-Mo-Al fuel and europium as burnable poison. Ann. Nucl. Energy 2016;92: 46-51.

10. H.J Ryu, J.M Park,Y.J Jeong, K.H Lee, Y. S. Lee, C.K Kim, Y.S. Kim. Post irradiation analyses of UMo dispersion fuel rods of KOMO test at Hanaro, Nucl. Eng. and Technology 2013:45:847-858.

11. Iman Kuntoro, Tagor MS. Desain teras alternatif untuk reaktor riset inovatif (RRI) dari aspek neutronik. J. Tek. Reaktor Nuklir 2014;16:1-10.

12. Lily Suparlina, Tukiran Surbakti. Analisis pola manajemen bahan bakar teras reaktor riset tipe MTR. J. Tek. Reaktor Nuklir 2014;14:178-191.

13. Tukiran, S. Pinem, Tagor M.S, Lily Suparlina, Jati Susilo. Desain konseptual teras reaktor riset inovatif berbahan bakar uranium molibdenum dari aspek neutronik. J. Tek. Reaktor Nuklir 2012; 3:179 - 191. 